\title{
Witnesses Inside/Outside the Stage. The Purpose Of Representing Violence In Edward Bond's Saved (1965) And Sarah Kane's Blasted (1995)
}

\author{
Testigos Dentro/Fuera Del Escenario. El Objetivo De La \\ Representación De La Violencia En Saved (1965) De \\ Edward Bond Y Blasted (1995) De Sarah Kane
}

\author{
Laura López Peña'
}

\section{Abstract}

In spite of the thirty years span of time between the two productions, Edward Bond's Saved and Sarah Kane's Blasted provoked a similar outburst of reactions when they first opened at the Royal Court Theatre in 1965 and 1995, respectively. Depicting various types of violence onstage, the two plays aim at making spectators connect different forms of cruelty so that they can be moved to react against them in real life. In order to do so, both plays highlight the question of witnessing at two levels: on the one hand, at the level of character, the plays portray individuals who witness, suffer and/or inflict brutality, becoming, thus, participants in the ongoing cycles of violence onstage; whereas, on the other hand, at the level of audience, spectators too become direct -and silent- witnesses to the plays and their depicted cruelties, at the same time that they are called to react against the horrors they have experienced in the theatrical fictional world. The aim of this paper is, therefore, to analyze how Saved and Blasted engage in arising spectators' awareness of their own passivity in front of several forms of violence, and invite their audience to actively denounce not only wars and conflicts taking place in distant places but also in their own immediate surroundings.

Key words

Contemporary British theater, Edward Bond, Sarah Kane, violence, witnessing.

\section{Resumen}

A pesar de los treinta años que separan ambas producciones, Saved de Edward Bond y Blasted de Sarah Kane provocaron reacciones similares cuando fueron estrenadas en el Royal Court Theatre en 1965 y 1995, respectivamente. Mediante la representación de varios tipos de violencia en escena, ambas obras pretenden conseguir que sus espectadores establezcan paralelismos entre las situaciones teatrales y las de la vida real para que, finalmente, sean capaces de rechazar la violencia en general y sus distintas manifestaciones en la sociedad. Para lograr este objetivo, tanto Saved como Blasted resaltan la cuestión de testimoniar a dos niveles. Por un lado, a nivel de personaje, ambas obras incluyen individuos que presencian, sufren y/o infligen algún tipo de crueldad y que, por lo tanto, participan en los continuos ciclos de violencia representados en el escenario. Por otro lado, a nivel de espectador, el público se convierte también en un testigo directo -y en un participante silencioso- de la obra y de la violencia que en ella se muestra. El propósito de este ensayo es, pues, analizar cómo Saved y Blasted invitan a sus espectadores a darse cuenta de su propia pasividad ante distintos tipos de injusticias con el objetivo de que éstos, eventualmente, sean capaces de denunciarlas y de actuar contra ellas en la sociedad.

1 I would like to thank Dr. Rodrigo Andrés (University of Barcelona) for having definitely contributed to the improvement of this paper with his careful -and always encouraging- reading and comments. I also thank Dr. Enric Monforte (University of Barcelona) for providing useful feedback.

Department of English and German Philology, Faculty of Philology, University of Barcelona. en3650@ wanadoo.es 
Palabras clave

Teatro británico contemporáneo, Edward Bond, Sarah Kane, violencia, testimoniar.

"If theatre can change lives, then it can change society. [...] Theatre is not an external force acting on society, but a part of it. It's a reflection of the way people within that society view the world."

Sarah Kane ${ }^{2}$

"Self-conscious societies such as ours need such plays [...]. They make you question values: yours, the playwright's, the world's. [...] theatre is only alive if it is kicking."

John Peter ${ }^{3}$

Despite their initially unsympathetic reception, Edward Bond and Sarah Kane have achieved recognition as two of the most paradigmatic and influential contemporary British playwrights. Although they embody two distinctive generations of dramatists speaking to and about their own times, both authors similarly convey a firm condemnation of the passivity with which society contemplates and continues perpetuating violence in its multiple and equally destructive manifestations. Their common aim of confronting -and of making spectators confront- violence is clearly present both in Bond's Saved (1965) and Kane's Blasted (1995), which depict different types of violence onstage in order to make audiences experience and, ultimately, react against them in real life. In this respect, both plays establish a connection between witnesses inside and outside the stage by engaging in a portrayal of characters who directly witness and, thus, participate -like spectators themselves- in the continuing cycles of violence presented.

Both Saved and Blasted generated, with few exceptions, harsh reactions in England when they were first staged. In the case of Saved, it was received with general hostility and condemnatory reviews, which deprecated the play as a "revolting and distasteful"

2 Sarah Kane in Sierz, 2001, p. 93.

3 Peter, 1995, p. 41. theatrical production or as "'a concocted opportunity for vicarious beastliness"' that was "'patently designed with no purpose above mere titillation"'.4 Before eventually being staged, the play did not escape the censorship of the Lord Chamberlain, which, in 1964, compelled it to undergo numerous cuttings and rewritings if it was to be performed at all. ${ }^{5}$ Bond, however, refused to introduce any modifications into his play, so that it was not until 1965 that Saved could finally be performed after the Royal Court strategically managed to temporarily become a club theater, the entrance of which was restricted only to its members. In the case of Blasted, a similar widespread scandal was repeated when it opened at the Royal Court Theatre Upstairs in 1995. Even though thirty years had passed since the first staging of Saved and censorship was no longer an officially operating mechanism in Britain, critics were equally outraged by Kane's explicit depiction of violence and sex. As Tom Sellar indicates, "[d] espite advances in social and aesthetic thought since the 1960s -or maybe because of them- these critics couldn't tolerate violence in a social indictment any more from Kane than from Bond".6 Most of these fierce condemnations were mainly concerned with the inclusion of what they considered to be gratuitous violence without any intention beyond the mere desire of scandalizing. As Kane herself remarked, people were, curiously, more upset about the representation of violence onstage than about violence itself, and went as far as to condemn the play as "[...] no more than an artful chamber of horrors, designed to shock and nothing more".7 Charles Spencer's review of the play was even more explicitly reproving:

4 These negative reviews of Saved are included in Roberts, 1986, p. 29.

5 The Lord Chamberlain constituted the official censor of theater productions in Great Britain between 1737 and 1968. For a more detailed discussion on the history of censorship in British drama see Shellard, Nicholson, and Handley, 2005.

6 Sellar, 1996, p. 31.

7 Curtis, 1995, p. 40. 
Blasted isn't just disgusting, it's pathetic. Miss Kane may kid herself that she has written a searing indictment of Britain today. What she has actually produced is a lazy, tawdry piece of work without an idea in its head beyond an adolescent desire to shock. [...]

Blasted is a work entirely devoid of intellectual or artistic merit. It seems sure to cause a rumpus, but the piece isn't even worth defending on the grounds of cultural freedom. ${ }^{8}$

Edward Bond was, among other playwrights like Harold Pinter or Caryl Churchill, one of the few (and most eager) defenders of Blasted. Considering that the play came " $[. .$.$] from the centre of our humanity$ and our ancient need for theatre", 9 he saw in Sarah Kane a young but promising playwright who -like him- believed drama a crucial and necessary instrument for the formation of a more humane and self-conscious society.

Contrarily to these initial reactions, with time, Saved and Blasted have attained recognition as prominent theatrical icons which, despite being products of different historical and social contexts, continue speaking to twenty-first century spectators as powerfully as they did when they were first staged. One of the major achievements of these plays is that their influence is not limited to the theater but tries to extend beyond it by entering the minds of spectators and by attempting to raise their awareness in order to, eventually, produce a change in their attitudes when facing real life and the real world. In this respect, witnessing is an emphasized theme in both plays that is highlighted at two different but mutually interconnected levels. On the one hand, at the level of character, both plays portray individuals who are direct witnesses of certain forms of brutality and who choose to remain passive about them. Due to their own inaction, these characters become direct or indirect participants in the ongoing cycles of violence described onstage, since they too are implicated into -and, therefore, responsible for- the

8 Spencer, 1995, p. 40.

9 Edward Bond in Saunders, 2002, p. 49. cruel events they are unable to disrupt. On the other hand, at the level of audience, spectators too become silent and, apparently, passive witnesses to the play and its depicted cruelties, at the same time that they are actively engaged into analyzing the roots of these violent events and invited to reject the passivity with which characters respond to them. This parallelism between witnesses inside and outside the stage serves both Edward Bond and Sarah Kane to appeal to their spectators' sensibilities as regards to the horrors they are made to (safely) experience in the theater, with the ultimate goal of calling their audience to move beyond the characters' (and their own) passivity and to react against violence in real societies and in everyday life.

As regards to witnesses inside the play, in the case of Saved, all characters encounter at some point a certain form of violence they can potentially confront. Immersed in the bleakness of a workingclass environment in Southern London, characters remain in a hopeless paralysis that blocks any possibility of moving beyond these social conditions. Their own incapacity to assume responsibilities and their tendency to pass blame onto each other makes it impossible for those individuals to interrupt the violence by which they are continuously surrounded and in which they are -directly or indirectly-involved. Throughout the play, Len emerges as the most evident and direct witness of violence, as Bond cleverly involves him, as a silent spectator, in the killing of Pam's baby in scene six, one of the most climactic events Saved portrays and the one that has most scandalized critics since 1965. In this scene, Len -who is the only character who, from the beginning, has actively shown some efforts to achieve certain improvement in their harsh living conditions- remains hidden, passively watching and without eventually attempting to stop Fred and his friends from their collective killing. Len confesses his inaction to Fred in the following episode, included in scene seven:

LEN. I saw.

[...]

I was in the trees. I saw the pram.

FRED: Yeh. 
LEN: I saw the lot.

FRED: Yeh.

LEN: I didn't know what t'do. Well, I should a stopped yer.

FRED. Too late now.

LEN. I juss saw.

FRED. Yer saw! Yer saw! Wass the good a that? $[\ldots]^{10}$

Len, then, becomes as implicated in the killing as Fred and the others for not putting an end to the violence he was silently witnessing and for allowing, thus, the described episode of cruelty to reach its culmination. ${ }^{11}$ In this respect, it is important to notice that the death of the baby is not presented as an individual assassination, the blame of which falls entirely over Fred and his friends; this incident is instead depicted as an economic and social murder, since it emerges unpremeditatedly as a consequence of the tough living conditions society imposes on lower-class people like them and which pushes them into a "culture based on contempt for life":12

There is no sadism in the attitude of the boys in this scene; their cruelty is cold, unfeeling. It is precisely because it is inexplicable in terms of straightforward emotional psychology that we are forced to consider the deeper psychological motivation which related their action to the social and economic situation. It is for this reason that Bond's realism is essentially philosophical and political. ${ }^{13}$

As a matter of fact, Bond's condemnation of this act of brutality does not center on the individual but on society, ${ }^{14}$ forcing spectators to relate Fred and

10 Bond, Edward (2000), Saved, p. 76.

11 Similarly, in scene four, Len-like the rest of the characters-remains inactive in front of the baby's endless and anxious crying. This already anticipates Bond's deliberately contradictory portrayal of Len as a passive and unresponsive individual who, despite realizing about the possibilities for changing Pam and her family's harsh conditions, is ultimately incapable of reacting.

12 Hirst, 1985, p. 53.

13 Idem, p. 53.

14 When referring to the controversial scene in which the stoning of Pam's baby takes place, in his opening notes to Saved, Bond observes the following: "Clearly the stoning to death of a baby in a London park is a typical English understatement. Compared to the 'strategic' bombing of cities it is a negligible atrocity. Compared to the cultural and emotional deprivation of most children its conse- his friends' joint action to the social and economic circumstances that have conditioned it. As Edward Bond himself remarks, "[v]iolence is not a function of human nature but of human societies": 15 "[...] the causes of human violence can be easily summed up. It occurs in situations of injustice. It is caused not only by physical threats, but even more significantly by threats to human dignity. [...] whenever there is serious and constant violence, that is a sign of the presence of some major social injustice". 16 Nevertheless, despite not blaming Fred and his friends directly for the murder of the baby, the play highlights the need of acting up against such acts of violence that society provokes and continues perpetuating. This is why, by the end of the play, Len emerges as a character who has learned from his inaction, understanding the necessity of getting implicated and of assuming responsibilities, something which encourages him to, eventually, stay with Pam and her family, facing the harshness of their everyday lives and, possibly, trying to construct a better future together. ${ }^{17}$ This hopeful ending supports Bond's avowal of his play as "almost irresponsibly optimistic",18 since:

It is true that at the end of the play Len does not know what he will do next, but then he never has done. The play ends in silent social stalemate, but if audiences think this is pessimistic that is because they have not learned to clutch at straws. Clutching at straws is the only realistic thing to do. The alternative, apart from the self-indulgence of pessimism, is a fatuous optimism. The gesture of turning the other cheek is often a way of refusing to look facts in the face. This is not true of Len. He lives with people at their most hopeless [...] and does not turn away from them. I cannot

quences are insignificant" (Saved, p. 5). As a matter of fact, when the play opened at the Royal Court Theatre, Bond astutely included William Blake's admonition "Better strangle an infant in its cradle than nurse unacted desires" in the program for Saved.

15 Bond, 1977, p. 17.

16 Idem, p. 13.

17 In this respect, the last image of Saved, in which Len is repairing the broken legs of a chair, can be read as pointing toward the possibility of constructing a better future for the whole family, as well as signifying Len's finally becoming a fully integrated member accepted by the family unit.

18 Bond, Edward (2000), Saved, p. 5. 
imagine an optimism more tenacious or honest than this. ${ }^{19}$

This positive reading of Saved as a hopeful play relates to Michael Billington's acknowledgement of Edward Bond as somebody who "retains a stubborn faith in humanity": "If Bond looks into the abyss, he also points to something beyond. 'You have to see how people deal with crisis', he [Bond] says. 'But in the end you cannot despair. If you're going to despair, stop writing. If my plays are staged and acted in the way in which they are written, what comes across is a colossal affirmation of life"'.20

Sarah Kane's plays are equally life-affirming. In the case of Blasted, the question of witnessing is likewise explicitly highlighted through the character of Ian, a forty-five year old middle-class journalist for Yorkshire whose job, apparently, makes him a regular reporter of events which, we soon discover, are related to violence at a local level. Yet Ian does not embody a humane type of journalism. As Peter Buse argues, in Blasted, "[t] he traditional role of the journalist as the bearer of historical testimony is reduced [...] to a hack churning out lurid clichés down a telephone". ${ }^{21}$ This assertion is clearly exemplified through Ian's cold and formulaic report of a horrifying murder, which he dictates down the phone to an unrevealed interlocutor:

A serial killer slaughtered British tourist Samantha Scrace, S - C - R - A - C - E, in a sick murder ritual comma, police revealed yesterday point new par. The bubbly nineteen year old from Leeds was among seven victims found buried in identical triangular tombs [...] point new par. [...] Samantha comma, a beautiful redhead with dreams of becoming a model comma, was on the trip of a lifetime after finishing her A levels last year point. Samantha's heartbroken mum said yesterday colon quoting, we pray the police will come up with something dash, anything comma, soon point still quoting. [... $]^{22}$

19 Idem, p. 5.

20 Edward Bond, in Billington, 2008.

21 Buse, 2001, p. 184.

22 Kane, Sarah (2002), Blasted, p. 13.
Ian, then, emerges as a detached and uncaring reporter whose stories about brutal events are narrated using an insensitive language that has been determined in advance in order to conceal the horror of the given incident and make facts more digestible for people. ${ }^{23} \mathrm{He}$ is, as Buse claims, a "bad witness" since "not only does he make the events he reports seem routine and commonplace but he is detached, both literally and symbolically, from those events". ${ }^{24}$ When the unnamed soldier appears in scene three, he requests Ian to report the brutal atrocities he has directly experienced and inflicted at war, insisting that, both as a journalist and as a direct witness (and sufferer) of violence himself, Ian should take on the responsibility of denouncing to the world that these stories are actually happening in order to help raising the consciousness of his readers. Ian, however, is not moved by the combatant's plea and refuses to get involved in what the soldier requires from him because -he says- nobody is interested in these types of events:

SOLDIER: Some journalist, that's your job.

IAN: What?

SOLDIER: Proving it happened. I'm here, got no choice. But you. You should be telling people.

IAN: No one's interested.

SOLDIER: You can do something, for me -

IAN: No.

SOLDIER: Course you can.

IAN: I can't do anything.

SOLDIER: Try.

IAN: I write... stories. That's all. Stories. This isn't

a story anyone wants to hear.

$[\ldots]$

SOLDIER: [...] Tell them you saw me.

Tell them... you saw me.

IAN: It's not my job.

[...]

Why bring you to light?25

23 Buse, 2001, p. 184.

24 Idem, p. 185.

25 Kane, Sarah (2002), Blasted, p.47-48. 
It is only after he has been raped and his eyes have been removed 26 that Ian realizes about the importance of witnessing and of bearing testimony, but, at this point, words fail him and he undergoes linguistic collapse as a result of his being unable to assimilate and articulate the trauma he has just experienced. ${ }^{27}$

Nonetheless, despite Ian's refusal to become an active denouncer of violence, Kane makes Blasted assume the humane role Ian has utterly rejected throughout the play. By connecting different types of violence (e.g. a rape in Leeds and the war in Bosnia),28 Kane is capable of denouncing violence in general and some of its multiple materializations; but, most importantly, this parallelism allows the playwright and her play to fiercely condemn society's unwillingness -like Ian's- to act up against such atrocities that are happening in reality, not only in places that we may perceive as remote and unrelated but also in our comfortable (British/Western) lives and so-called civilized countries. Considering that Kane keeps the unity of location in Blasted (she brings the chaos and suddenness of a civil war into Leeds), 29 this formal strategy reinforces even more

26 As a matter of fact, throughout the second half of the play, Ian undergoes both a dehumanizing and a humanizing process, as, on the one hand, he is dehumanized from his former violent, uncaring and insensible type of humanity and, on the other, this dehumanization enables him to finally embrace a new kind of humanism which makes him capable, by the very end of the play, of uttering the significant words "thank you" to Cate.

27 Buse, 2001, p. 185.

28 "Originally, I was writing a play about two people in a hotel room, in which there was a complete power imbalance, which resulted in the older man raping the younger woman. [...] At some point during the first couple of weeks of writing (in March 1993) I switched on the television. Srebrenica was under siege. An old woman was looking into the camera, crying. She said, 'Please, please, somebody help us. Somebody do something'. I knew nobody was going to do a thing. Suddenly, I was completely uninterested in the play I was writing. What I wanted to write about was what I'd just seen on television. [...] Slowly, it occurred to me that the play I was writing was about this. It was about violence, about rape, and it was about these things happening between people who know each other and ostensibly love each other" (Kane in Sierz, 2001, p. 100-101).

29 The stage directions which open scene three inform spectators that "[t]he hotel has been blasted by a mortar bomb" creating a "large hole in one of the walls" and covering everything in dust (Blasted, p. 39). This explosion introduces a disruption into the play's dramatic shape. However, whereas some critics (and Kane herself) have argued that the unity of location is maintained because -through the blast- a civil war is made to unexpectedly break into Britain, others the interconnectedness between specific manifestations of violence regardless of the place in which they originate, which suggests "a paper-thin wall between the safety and civilization of peacetime Britain and the chaotic violence of civil war. A wall that can be torn down at any time, without warning."30 By turning Leeds into a battleground, Kane deconstructs the general belief which considered that Britain could never be touched by a civil war, ${ }^{31}$ and connects a common rape in Leeds with the multiple horrors of war: 32

I asked myself 'What could possibly be the connection between a common rape in a Leeds hotel room and what's happening in Bosnia?' And then suddenly the penny dropped and I thought 'Of course, it's obvious. One is the seed and the other is the tree.' And I do think that the seeds of full-scale war can always be found in peacetime civilisation and I think the wall between so-called civilisation and what happened in central Europe is very, very thin and it can get torn down at any time. ${ }^{33}$

The ultimate aim of Kane is, thus, to increase spectators' awareness and to persuade them of the need to react against violence in near and distant places. In this respect, the play, like Bond's Saved, is full of optimism. As Kane notes, "[f] or me the play was about a crisis of living. How do we continue to live when life becomes so painful, so unbearable? Blasted really is a hopeful play because the charac-

interpret the explosion as a rupture of the unity of place, believing that, in the second half of the play, characters and spectators are transported into a war zone somewhere outside Britain. For a more detailed discussion on the structure of Blasted see Saunders, 2002 p. 37-70.

30 Kane in Saunders, 2002, p. 45.

31 Sierz, 2001, p. 98.

32 Kane includes three rapes in her play, which are interrelated and which serve the playwright to reinforce the interconnectedness between these dehumanizing acts at different levels. In this respect, the soldier's rape of lan at the end of scene three is a re-enactment of other soldiers' rape and murder of the anonymous combatant's dead girlfriend Col, at the same time that this traumatic experience of which lan becomes a victim points both toward the latter's own raping of Cate (in scene one), at the private level, and, in more general terms, toward the brutal rapes that are frequently perpetrated on civilians in times of war.

33 Kane in Billington, 2007, p. 356. 
ters do continue to scrape a life out of the ruins"; 34 "I don't find my plays depressing or lacking in hope [...]. To create something difficult about despair, or out of a feeling of despair, is for me the most hopeful, life-affirming thing a person can do".35 Similarly, Edward Bond regarded Sarah Kane's Blasted as a "dangerous and dark prediction of the future, like some of his own plays. Because that future devastation is imagined and not yet realized (at least not everywhere), Bond sees it as something the humane spectator can struggle against, something to resist": 36

[...] If we do not confront it [the implacable] and find our humanity, it will confront us and destroy us. That is the logic of the twenty-first century.

At some time in that century everyone -alone or collectively- will confront the implacable. Without the elucidation of drama they will not know till too late -if at all- what is happening. ${ }^{37}$

Blasted, like Saved, is a hopeful play that invites us to reject violence. Both productions are as much alive today as when they were first written and staged, as they continue inviting audiences from different places and periods of time to transcend Len

\section{Works Cited}

Billington, Michael (2008), "If You're Going to Despair, Stop Writing' (Interview with Edward Bond)", in The Guardian, 3 January 2008. Access: 3 Nov. 2008. <http://arts.guardian.co.uk/theatre/drama/ story/0,,2234520,00.html>

Billington, Michael (2007), "Picking Up the Pieces: 1990-97", in State of the Nation: British Theatre Since 1945. London: Faber and Faber.

Bond, Edward (1977), “Author's Note 'On Violence”, in Plays: 1. London: Methuen.

Bond, Edward (2000), Saved. London: Methuen.

Bowen, Kirsten (2005), "Edward Bond and the Morality of Violence", in American Repertory Theatre, Num.

34 Kane in Sierz, 2001, p. 106.

35 Idem, p. 91.

36 Sellar, 1996, p. 34.

37 Edward Bond in Saunders, 2002, p. 191. and Ian's silent witnessing and assume a common responsibility that denounces and interrupts the maintenance of violence in society. In this respect, both Sarah Kane and Edward Bond report in their plays several manifestations of violence to spectators who become outside witnesses to the plays by being put through the callous acts happening onstage, so that they can experience their brutality and -like Len or Ian- ultimately become aware of the need to assume a humane responsibility and react against the several injustices that take place in actual societies around the world, both near and distant. As Bond claims, "[v]iolence shapes and obsesses our society, and if we do not stop being violent we have no future. People who do not want writers to write about violence want to stop them writing about us and our time. It would be immoral not to write about violence." 38 After all, perhaps theater can become one of the means we need to confront the implacable and help us define our humanity.

3, Vol. 3 (April 2005). Access: 3 Nov. 2008. <http:// www.amrep.org/articles/3_3a/morality.html>

Buse, Peter (2001), Drama + Theory: Critical Approaches to Modern British Drama. Manchester and New York: Manchester University Press.

Curtis, Nick (1995), ["Review of Blasted"], in Theatre Record, Num. 15, Vol. 1-2 (January 1995), p. 40.

Hirst, David L. (1985), Edward Bond. Basingstoke and London: Macmillan.

Kane, Sarah (2002), Blasted. London: Methuen.

Peter, John (1995), ["Review of Blasted"], in Theatre Record, Num. 15, Vol. 1-2 (January 1995), p. 41.

Roberts, Philip (1986), The Royal Court Theatre: 19651972. London and New York: Routledge \& Kegan Paul.

38 Edward Bond in Bowen, 2005. 
Saunders, Graham (2002), 'Love me or Kill me': Sarah Kane and the Theatre of Extremes. Manchester and New York: Manchester University Press.

Sellar, Tom (1996), “Truth and Dare: Sarah Kane's Blasted", in Theater, Num. 27, Vol. 1, p. 29-34.

Shellard, Dominic; NICHOLSON, Steve; and HANDLEY, Miriam (2005), Lord Chamberlain Regrets: A History of British Theatre Censorship. London: British Library Publishing.
Sierz, Aleks (2001), In-Yer-Face Theatre: British Drama Today. London: Faber and Faber.

Spencer, Charles (1995), ["Review of Blasted"], in Theatre Record, Num. 15, Vol. 1-2 (January 1995), p. 40.

Artículo recibido el 3 de febrero de 2009 y aprobado el 28 de abril de 2009 